\title{
EDITORIAL
}

\section{So Long...}

For the past 5 years, I have had the good fortune to serve as Editor-in-Chief of this journal. While I can't say that I've enjoyed every minute of it (my predecessor, Peter Mueller liked to say the job makes you the "most hated person in interventional radiology"), it has (at times) been engrossing, (at times) all-encompassing, and (at times) even fun. I've amassed a great deal of invaluable knowledge. Some of it is relevant only to future editors. The three most important rules I learned are that editorial "final firm hard-and-fast deadlines" are only suggestions. In general, "Author Instructions" take too long to read to be used appropriately even when in tabular form. And nearly every correspondence from an author ends in, "What CME questions?" Suffice it to say, any success that I have had in this position is largely attributable to the fantastic support I receive from the staff at Thieme. It is impossible for me say enough about the outstanding service rendered by them during my tenure.

Congratulations and I'm sorry to the new most hated man in interventional radiology, Charles E. Ray, Jr., M.D., Ph.D., FSIR, (insert additional letters here), Professor and Chief of Interventional Radiology at the University of Colorado Health Sciences Center. Exactly 3 years my senior (we were both born on October 9 for anyone wanting to send gifts—send his gifts to me), Chuck serves on the Executive Council of the Society of Interventional Radiology, is Chair of the American College of Radiology's Appropriateness Committee in
Interventional Radiology, and co-editor of Updates in Interventional Radiology, which will be published through the Society of Interventional Radiology next year. He finds the time to do all of this by eschewing sleep, vacations, and all hair care products. Although he has no idea what he has just agreed to do, importantly for him, his wife is a $2^{\text {nd }}$ degree black belt in Tae Kwan Do so future authors are advised to submit their contributions on time.

A few "thank you's":

- To the brains and glue of the operation (you can decide who is who): Daniel Schiff, Sergio Cardoso, David Stewart, Dawn White, and everyone at Thieme. I'll miss the e-mails.

- To all the guest editors and authors. Thank you for the time, effort, and outstanding contributions.

- To the Editorial Board. You made me look good by having my name next to yours.

Finally, to the five or so of you out there who have had the patience to read my thoughts and musings in this column, thank you and see ya!

All the best.
Brian Funaki, M.D. ${ }^{1}$ Editor in Chief
${ }^{1}$ Section of Vascular and Interventional Radiology, University of Chicago Medical Center, Chicago, Illinois.

Address for correspondence and reprint requests: Brian Funaki, M.D., Professor and Section Chief, Section of Vascular and Interventional Radiology, University of Chicago Medical Center, 5840S. Maryland Avenue, MC 2026, Chicago, IL 60637.

Genitourinary Intervention; Guest Editor, Darryl A. Zuckerman,
M.D.

Semin Intervent Radiol 2011;28:359-360. Copyright (C) 2011 by Thieme Medical Publishers, Inc., 333 Seventh Avenue, New York, NY 10001, USA. Tel: +1(212) 584-4662.

DOI: http://dx.doi.org/10.1055/s-0031-1296077.

ISSN 0739-9529. 